\title{
Use of Professional Accountants' Advisory Services and its Impact on SME Performance in an Emerging Economy: A Resource-based View
}

\author{
Yahya Kamyabi (Corresponding author) \\ Faculty of Business \& Accountancy, University of Malaya \\ Lembah Pantai 50603, Kuala Lumpur, Malaysia \\ Tel: 60-17-282-1350 E-mail: ykamyabi344s@yahoo.com
}

Susela Devi

Faculty of Business \& Accountancy, University of Malaya

Lembah Pantai 50603, Kuala Lumpur, Malaysia

Received: March 16, 2011 Accepted: May 4, 2011 doi:10.5539/jms.v1n1p43

\begin{abstract}
This paper aims to identify the factors that affect the decisions of managers of manufacturing sector SMEs in Iran to utilise external accountants' advisory services and to examine the effect of these advisory services on SME performance using the Resource-Based View (RBV) of the firm as the theoretical lens in the Iranian SME manufacturing sector. A questionnaire survey of 658 Iranian manufacturing SMEs is used. The results of linear regression analysis suggest that the use of external accountants' advisory services is positively associated with the knowledge of owner/manager, technical competence, competitive intensity and complexity of market decisions. In addition, the study evidences that the use of advisory services has a positive effect on SME performance. Furthermore, after controlling for age and size of the firm, the relationships between four independent variables (knowledge, technical competence, competitive intensity and complexity of market decisions) and utilisation of advisory were remained significant.
\end{abstract}

Keywords: Advisory services, Professional accountant, Resource-based view (RBV), SMEs and performance

\section{Introduction}

Small and Medium-Sized Enterprises (SMEs) play an important role in all over the world as to their contribution to the total productivity and job opportunities (Blackburn and Jarvis, 2010; OECD, 2009). For example, SMEs in Iran are a most significant source of employment generation and diversification of economy as in many other developed and developing countries around the world (Ale-Ebrahim et al., 2010; Bayati and Taghavi, 2007; Zohari, 2008). However, majority of SMEs in emerging economy cannot compete in an effective way due to a gap in their internal resource base (Kamyabi and Devi, 2011; UNIDO, 2003). Indeed, in this globalised era, as competitive pressures intensify, smaller firms are forced to lessen their costs and create new opportunities through optimized utilisation of external resources (Mahmoodzadeh et al., 2009). Evidently, the new competitive environment is more complex (Espino-Rodríguez and Padrón-Robaina, 2004), and furthermore, SMEs cannot control the markets in which they operate (Bennett, 2008).

The majority of SMEs tend to fail because of the lack of planning, marketing knowledge, absence of managerial skills and competencies or capabilities (Dyer and Ross, 2008). Moreover, "SMEs in global value chains are even more vulnerable as they often bear the brunt of the difficulties of the large firms" (OECD, 2009, p. 6). Therefore, SMEs needs more business support and advice because of both their economic contribution and their vulnerability to market imperfections (Blackburn et al., 2010; Lowe and Talbot, 2000). By relying on external sources, SMEs can obtain the capabilities and knowledge they need from external service providers (Gilley et al., 2004). In fact, activities in which SMEs lack the necessary resources (i.e. knowledge and skills or expertise and competence) internally can be obtained from external service providers (McIvor, 2009). Hence, Resource-Based View (RBV) states that the limited resource of smaller firms makes it essential for them to obtain resources from external sources (Kamyabi and Devi, 2011). In this context, a transformation in professional accountants' services to their small business clients is critical (Kamyabi and Devi, 2011; Blackburn and Jarvis, 2010). 
External accountants can assist SMEs operating in a competitive environment, to integrate operational considerations within long-term plans (Ismail and King, 2005) to enhance their sustainability.

The RBV can also assist with analyzing SME resources, which can link external sources (outsourcing) with performance (McIvor, 2009). In effect, the RBV argues that SME owners/managers use external accountants as a source of professional services chiefly as a result of a gap in their internal resource base (Doving and Gooderham, 2008; Gooderham et al., 2004). For instance, professional accountants are seen as business links for SMEs to seek advisory services and support (Lowe and Talbot, 2000). Thus, a major concern of the RBV is how a company's resources develop and affect its performance (McIvor, 2009). However, empirical studies examined the effect of the use of accountants' advisory services on SME performance (Bennett and Robson, 1999; Berry et al., 2006; Robson and Bennett, 2000). However, these are conducted in more developed economies wherein the effect of advisory services on SME performance is examined. Moreover, the results are inconclusive. It is also argued that empirical evidence from the most developed economies may not be as applicable to economies such as Iran (Mashayekhi and Mashayekh, 2008) due to differing institutional context (Devi and Samujh, 2010) and level of state intervention in economic activities (Ismail and Zin, 2009). For example, there are several reasons that Iranian SME environment is difference form that of developed countries: (1) inadequate accounting and management, (2) the cost of access to information is too high, (3) financial barriers (e.g. absence of specific credit facilities), (4) public policy shortcomings (e.g. legal barriers), (5) poor management and (6) unskilled workers (UNIDO, 2003).

Given that the nature of accountants' services is people-intensive (Everaert et al., 2010), and that there is a resource gap and competitive environment faced by SMEs (Blackburn and Jarvis, 2010), it is timely to explore whether the provision of external accountants' advisory services is associated with SME performance in an emerging economy. Hence, this paper aims to identify the factors that affect the decisions of managers of manufacturing sector SMEs in Iran to utilise external accountants' advisory services and to examine the effect of these advisory services on SME performance using the Resource-Based View (RBV) of the firm as the theoretical lens in the Iranian SME manufacturing sector.

The rest of the discussion is organised as follows: Section 2 provides the background of study and develops hypotheses utilising the RBV as a theoretical framework to investigate the use of advisory services. Section 3 explains the research methodology. Section 4 presents the findings. Section 5 discusses the implications with suggestions for future research.

\section{Background of Study}

\subsection{An Overview of the Iranian Economy}

Iran has a population of 73 million (Nejad, 2010). Iranian economy is largely dependent on oil revenue (ILO, 2003). For instance, Iran is the second largest oil producer of OPEC after Saudi Arabia (Ghanatabadi, 2005). In fact, the dependence on oil exports placed the Iran's economy in a weak position (UNIDO, 2003). For example, "With about 19 percent of the population living below the poverty line, the GDP of $\$ 599.2$ billion, the real growth rate of 4.3 percent, unemployment rate of about 22 percent and inflation rate above 18.5 percent, the country has a very challenging and unstable economical situation" (Zohari, 2008, p.18). Hence, one of the most challenging problems in Iranian economy is to facilitate and produce new jobs for those who are ready to enter the labor market for unemployment position in Iran (Nejad, 2010). Accordingly, recognizing the importance of SMEs in generating employment, Iran's national development plans (Third Economic Plan (1999-2004) and The Fourth National Development Plan (2005-2009)) continue to place a great deal of importance on their growth (Feizpour and Jamali, 2009; Ghanatabadi, 2005; ILO, 2003).

\subsection{Small and Medium Enterprises (SMEs) in Iran}

There is a little agreement regarding the definition of SMEs in Iran, but the Iranian Statistical Yearbook categorizes enterprises into four classes, e.g. businesses with 1-9 employees, 10 to 49 employees, 50 to 99 employees, and more than 100 workers (UNIDO, 2003). However, most studies in Iran define SMEs in terms of number of employees in the range of less than 250 employees (Kamyabi and Devi, 2011; Ale-Ebrahim et al., 2010; UNIDO, 2003; Zohari, 2008). However, "more than 63 percent of total Iranian manpower in the industrial sector are employed by SMEs, and the share of SMEs in value amounts to approximately 30 percent, and, in total, represents 99.9 percent of all businesses in Iran" (Zohari, 2008, p.7).

\subsection{Professional Accountants and Financial Reporting in Iran}

As a result of the privatisation programmes in 1991, the Iranian Association of Certified Public Accountants (IACPA) was established in 2001 as an independent professional body (Mashayekhi and Mashayekh, 2008). 
Therefore, the law requires the use of a member of the Iranian Association of Certified Public Accountants (IACPA), to audit all listed public Companies, Public joint stock companies, natural persons and legal entities whose turn-over exceeds eight billion Rials (800000USD) annually or whose total assets exceed sixteen billion Rials must be audited (ArabSalehi and Velashani, 2009). Iran has over one million firms (including SMEs and large firms), but only 10000 of those firms should be audited (Naderian, 2010). Thus, our point is that for those SMEs that are not audited they still require accountants' services and where advisory services are used it enhances their performance.

In Iran, the term "professional accountant" or external accountant refers to members of IACPA and the partners of accounting firms with valid practising certificates who can hold themselves out as CPAs, and set up firms providing accounting, audit, tax and other services (Kamyabi and Devi, 2011;Naderian, 2010). In Iran, the largest accounting firms have less than 200 employees, so there is a big gap between these firms and the international accounting firms in terms of size (Naderian, 2010). However, there is no Big 4 accounting firms operating in Iran, and all Iranian accounting firms are small(Naderian, 2010). IACPA is an Iranian accountancy body with 1684 members which offers the Certified Public Accountant (CPA) qualification (http://www.iacpa.ir). In fact, professional accountants play a vital role in Iranian SME environment which encompass about ninety percent of enterprises of Iran (Mirshekary and Saudagaran, 2005). Although SMEs' access to a wide variety of advisory services, such as banks, is available, it is expected that the external accountant would play a key role in assisting SME owner/managers to manage their firms effectively (Marriott and Marriott, 2000; Mole, 2002) and such need is more apparent in emerging economies (Devi and Samujh, 2010).

\subsection{External Accountants' Advisory Services}

In the UK, many empirical studies show that smaller enterprises used professional accountant as a source of advisory and support services (Berry et al., 2006; Kirby et al., 1998; Scott and Irwin, 2009). In Norway, Gooderham et al. (2004) revealed that professional accountants are a reliable provider of advisory services and support in small companies. In Australia, many claimed that external accountants have provided financial management and support services for the SME sector (Carey et al., 2005; Leung et al., 2008). In New Zealand, Lewis et al. (2005) found external accountants were the main source of advice in terms of frequency, usefulness and significance of advice in SME context. In summary, whilst this research was undertaken in more developed economies, literature on role of professional accountants in emerging economies such as Iran is missing except for the limited research conducted in Malaysia (Devi and Samujh, 2010).

\section{Theoretical Framework and Hypotheses}

Resource Based-View (RBV) was developed by Penrose (1959) who suggested that a company should be considered as a collection of physical and human resources bound together in an organizational structure. Furthermore, Hafeez et al. (2007) classified resources as physical assets and intellectual assets. Physical assets (i.e. plant and equipment) are easily distinguishable due to their tangible existence (Hafeez et al., 2007). Intellectual capital is relevant to the intangible aspect of human resource such as employee skill, knowledge and individual competencies (Hafeez et al., 2007). Overall, the RBV addresses two key points (Gottschalk and Solli-Sæther, 2005). First, the RBV indicates a resource should provide economic value and must be currently scarce, difficult to imitate or copy, non-substitutable, and not readily accessible in factor markets to create competitive advantage (McIvor, 2009). Second, resources determine firm performance (Gottschalk and Solli-Sæther, 2005; McIvor, 2009). In the context of accounting, resources mainly refer to knowledge, skill and competence (Everaert et al., 2006; Jayabalan et al., 2009). For instance, explicit knowledge in accounting functions is knowledge of generally-accepted accounting rules (Everaert et al., 2006). However, applying those rules in a business environment requires tacit knowledge (Everaert et al., 2006). For professional accountants, tacit knowledge chiefly is acquired through practice, which makes it almost unattainable to transfer (Kamyabi and Devi, 2011; Hafeez et al., 2007). However, SMEs lack qualified people or knowledge to fulfill the accounting functions (Kamyabi and Devi, 2011; Everaert et al., 2006). Hence, the RBV explains successfully a number of respects of accounting for differences in the provision of advisory services by external accountants (Doving and Gooderham, 2005). Interestingly, consistent with the RBV theorisation, SMEs use professional accountants as sources of support services and advice to fill up gaps in their internal resource(Kamyabi and Devi, 2011; Doving and Gooderham, 2005; Everaert et al., 2006; Gooderham et al., 2004; Marriott et al., 2008). Therefore, the RBV of the firm provides a theoretical grounding for the assessment of firm-specific factors that are potentially affect the SME performance (Irwin et al., 1998).

\subsection{Owner/Manager Knowledge}

The RBV argues if SMEs are to grow, they need to obtain expert knowledge from external service providers and 
then embed the knowledge into their firms (Worrall, 2007). Moreover, RBV explains that SMEs are unable to carry out the accounting functions internally because of inadequate knowledge and unqualified employees (Everaert et al., 2006; Jayabalan et al., 2009). For example, SMEs lack the necessary skills and resources to perform accounting functions in-house; access to the expertise and specialized knowledge of a professional accountant was evidently the most important reason to outsource (Everaert et al., 2006). However, many claimed that SME managers are not aware of the range of support and advisory services available to them (Ismail and King, 2007; Ismail and Zin, 2009; Liddicoat and Stringer, 2005), due to the unavailability of sufficient evidence of the benefits of such services (Watson, 2003), or lack of support in seeking relevant information (Devi and Samujh, 2010). In fact, sophisticated SME owner/managers may be aware of the benefits of compensating their own inadequate knowledge or skills by utilising external service provider (Ismail and King, 2007; Watson, 2003). For example, Audet and St-Jean (2007) revealed that the SME owner/managers, who knew more about the external service providers, used those services more than SME owner/managers who did not have any information about these services. However, less sophisticated and incapable SME owner/managers might be unaware of their own weaknesses to ask for support and advice, believing they can do it all themselves (Watson, 2003). Hence, it is hypothesized that:

H1: Firms with owner/managers having high levels of knowledge in accounting will utilise external accountants' advisory services more than those firms that with owner/managers having low levels of knowledge.

\subsection{Technical Competence}

The RBV postulates that SME owner/managers must understand why competences should be obtained as valuable resources to improve firm performance (Caldeira andWard, 2003). The RBV argues activities which are not significant to the core competencies must be obtained from external sources (Gilley et al., 2004). Carey et al. (2006) explained that attributes of technical competence to a professional accountant include appropriate qualifications and experience, essential specialized skills, industry specialization and technological expertise. Indeed, majority of SME owner/managers have no professional, management and other formal qualifications (Kamyabi and Devi, 2011). One possible way for a smaller firm to acquire competencies is to engage professional accountant (Gooderham et al., 2004). Therefore, by relying on professional accountant, smaller firms can get the competence that they need (Carey et al., 2005; Carey et al., 2006). Moreover, the reliance by SMEs on external accountants is perceived to be a result of the perceptions of SMEs that professional accountants are competent and can provide a value-for-money (Leung et al., 2008). Evidently, empirical research shows that technical competence of the external accountant is positively associated with the use of accountants' services (Carey et al., 2005; Carey et al., 2006; Gooderham et al., 2004). Consequently, the earlier arguments are summarised in the following hypothesis:

$\mathrm{H} 2$ : The higher the perception that an external accountant has high technical competence in offering accounting tasks, the greater the propensity to use external accountants' advisory services.

\subsection{Competitive Intensity}

SMEs are unable to continue when they face intense competitive pressure because their resource gap does not permit them to adapt their product (Gooderham et al., 2004; Blackburn and Jarvis, 2010; Kamyabi and Devi, 2011). For example, RBV explains the firm facing intense competition needs more resources and support than the firm that does not face competitive pressure (Gooderham et al., 2004; Worrall, 2007; Kamyabi and Devi, 2011). More importantly, in the competitive condition, SME owner/managers should learn how to exploit external resources to assist their enterprises to become more productive and competitive (Worrall, 2007). Referring to earlier discussion, one possible way to lessen competitive pressure and gain sufficient resource and competences is to employ qualified accountant (Kamyabi and Devi, 2011; Gooderham et al., 2004). However, given the insufficient number of qualified professional accountants, we expect SMEs will turn to external accountants for advisory and support services (Berry et al., 2006; Devi and Samujh, 2010) as advice and support services comprise a range of competencies and knowledge that are much significant for the firm survival and gaining competitive advantage (Gooderham et al., 2004). For example, Gooderham et al. (2004) indicate that when a smaller company is faced with vulnerable competition, they refer to an external accountant as a source of support and advice to attain competitive advantage. As a result, our hypothesis based on the earlier discussion is as follows:

H3: The firms that face more intense competition will utilise more external accountants' advisory services.

\subsection{Complexity of Marketing Decisions}

The RBV explains that smaller enterprises need to acquire external support and advice to broaden their market 
for achieving competitive advantage (Marriott et al., 2008). In fact, the need of a firm owner/manager to obtain external support and advice is dependent on the nature of the market within which the firm is operating (Johnson et al., 2007). For example, when a company is operating in the local market, they might be able to drive the business based on its internal resource and may only need limited external support (Johnson et al., 2007). Moreover, the firm owner/managers may be expert or proficient in the product markets within which they work, they may not be proficient in accounting and financial management issues, or may lack other important skills and expertise (Collis and Jarvis, 2002; Devi and Samujh, 2010; Marriott and Marriott, 2000; Pineda et al., 1998). Although market issues are not legalised by statute, as accounting issues, Pineda et al. (1998) reported that SME managers may treat this area of expertise in the same way as they perceive accounting issues or financial management issues; they may engage professional accountants advice and information when they make marketing decisions on product quality, product lines and pricing (Blackburn and Jarvis, 2010; Pineda et al., 1998). However, evidence suggests that SME owner/managers seek specialised advisory and support services from an external accountant where needed (Sian and Roberts, 2009). Dyer and Ross (2008) found that complexity of marketing decisions is significantly associated with business advice. Thus, we hypothesise a positive association between the use of advisory services and complexity of marketing decisions as follows:

H4: The higher the complexity of the marketing decisions facing the SMEs, the higher the use of external accountants' advisory services.

\subsection{SME Performance}

The RBV argues that resources are the determinants of firm performance (Gottschalk and Solli-Sæther, 2005; McIvor, 2009). Bennett and Robson (1999) examined the association between SMEs' utilisation of the external accountants' business advice and employment growth. Bennett and Robson (1999) categorized three growth categories: (i) declining/stable, (ii) medium growth, and (iii) fast growth. They concluded that the external accountants' business advice is related to employment growth. Additionally, Robson and Bennett (2000) examined the relationship between business advice provided by an external accountant and SME performance. They categorized performance in three groups (1) change in number [of staff] employed by client, (2) percentage change in firm turnover and (3) change in profitability per employee. However, they did not find a positive relationship between business advice and SME performance. Furthermore, Berry et al.(2006) examined the effect of four types of accountants' advisory services (business advice, emergency advice, financial management support and statutory advice) on SME performance (growth). They report that "the degree of use of a range of external advice was positively related to the growth rate of SMEs" (p33). Hence, we hypothesise that the firm performance is associated with direct use of external accountants' advisory services as follows:

H5: There is a positive relationship between firm performance and utilisation of external accountants' advisory services.

\section{Method}

\subsection{Sample}

According to prior studies as discussed earlier, we defined SMEs as companies employing fewer than 250 employees and excluded micro firms because Small and medium sized enterprises (10-250 employees) account for a relatively large share of Iran's exports (UNIDO, 2003). We utilised the Iran Small Industries \& Industrial Parks Organization (ISIPO) database (http://www.iraniec.ir), excluding services and public companies, and included only manufacturing sector SMEs fewer than 250 workers. This resulted in a population of 17,100 enterprises. Then, we selected a sample of 1750 manufacturing SMEs randomly, using a systematic probability method. A questionnaire survey was designed and developed based on prior studies, and then the questionnaires were sent to each SME owner/manager by post mail at 5 March 2010. Hence, we conducted two stages to collect data. In the first stage of the data collection, from 1750 questionnaires distributed, only twenty percent (350 questionnaires) were collected. Due to the low response rate, the second stage of data collection was conducted. Questionnaires with a reminder letter were sent again to those SME owner/managers who had not responded to the questionnaire survey. Another 420 responses were received, giving a total of 770 respondents. Nevertheless, 112 questionnaires were excluded because of the repeated or incomplete responses by the respondents. However, we finally had only 658 usable answers, representing an effective response rate of 38 percent. The response rate is very high in contrast to preceding research of SME context by Everaert et al. (2007) who obtained a low response rate (10 percent). In addition, based on suggestion by Armstrong and Overton (1997), we tested for response bias by examining the differences between the early and late respondents in terms of model variables, so we did not find any significant differences. 


\subsection{Variable Measurement}

\subsubsection{Dependent Variables}

Firm Performance was previously tested and validated by Sarapaivanich and Kotey (2006). Thus, we first asked respondents to indicate the level of the importance attached to the four financial (profitability, growth in sales, return on assets and cash flow) and three non-financial (lifestyle, independence and job security) performance goals on a 7-point Likert type ranging from 1-not at all important to 7-very important. Then, respondents were asked to indicate their satisfaction with the seven financial and non-financial performance goals over the previous two financial years on a 7-point Likert type ranging from 1-strongly dissatisfied to 7-very satisfied. This variable was shown to have satisfactory reliability in the sample (Cronbach's $\alpha=0.98$ ).

Utilisation of advisory services comprises five types of services (tax consultancy, business advice, management consultancy, financing advice and IT consultancy) provided by Iranian professional accountants to SME sector which are similar to that derived from Doran (2006). Consequently, we utilised the measurement developed by Gooderham et al. (2004), asking participants to indicate to what extent they utilise an external accountant as advisor relating to each item using a 7-point Likert type, where 1- not at all to 7- very large degree. The measure of variable was displayed an adequately high Cronbach's alpha $(\alpha=0.88)$.

\subsubsection{Independent Variables}

Owner/Manager Knowledge includes with nine items (financial accounting techniques, management accounting techniques, word-processing package, spreadsheet package, database package, accounting-based applications, computer-assisted production management, e-mail and internet searching) that was developed by Ismail and King (2007). By using this measurement, we asked respondents to indicate the level of their knowledge of the accounting techniques and IT applications on 7-point Likert type from 1-no knowledge to 7-extensive knowledge. This variable has adequate reliability in the sample (Cronbach's $\alpha=0.90$ ).

Technical Competence was measured with six items (specialized industry wide knowledge, expertise in internal control, experience and qualifications, depth of understanding of your organization, expertise in computerized information systems accounting and expertise in risk management) developed by Carey et al. (2006), asking respondents to specify the degree to which the firm perceives their external accountant as a technical competent source of accounting and advisory services, using 7-point Likert scale where 1-lowest score and 7- highest score. This variable has a satisfactory reliability in the sample (Cronbach's $\alpha=0.90$ ).

Competitive Intensity included five items (product characteristics, promotional strategies among rivals, access to distribution channels, service strategies to customers and product variety) derived from Rivard et al. (2006). We utilised the measurement that applied by Rivard et al. (2006), asking respondents to record the intensity of their firm competition regarding each item on a 7-point Likert scale from 1- very weak competition to 7-very fierce competition. The measure of variable was found an adequately high Cronbach's alpha $(\alpha=0.80)$.

Complexity of Marketing Decisions with four items (having a large number of customers, selling to numerous market segments, having broad geographical markets, innovative marketing techniques and developing innovative) was taken by Dyer and Ross (2008). Accordingly, we asked participants to identify the factors that affect the success of their business on a 7-point Likert scale, 1- not at all significant, and 7- extremely significant. The measure of variable was found to have reasonable reliability in the sample (Cronbach's $\alpha=0.78$ ).

\subsubsection{Control Variables}

The RBV indicated that the use of external services interacts with the size and age of the firm (Bennett and Robson, 2003). Empirical studies indicate that utilisation of advisory services by SMEs is positively related to firm size and firm age (Bennett and Robson, 1999; Dyer and Ross, 2008). Furthermore, previous research has suggested that entry mode choice and performance may be influenced by firm size and firm age (Dyer and Ross, 2008). Consequently, we included firm size and age as control variables. Therefore, firm Size was measured by number of employees similar to prior study (Audet and St-Jean, 2007). In addition, firm age was measured by the number of years a business had been in existence (Doran, 2006).

\section{Results}

\subsection{Descriptive Statistics}

Our sample included 78 percent male and 22 percent female. Most of the respondents were quite well educated, and the general level of managerial experience was high with nearly three-fourth of respondents having over five years of experience.

Table 1 reports the means, standard deviations and correlations for the variables utilised in the present research. 
Hence, we didn't find correlations more than $70 \%$ between independent variables, so the correlation between independent variables was such that multicollinearity is not a concern.

\subsection{Hypotheses Testing}

The multiple linear regression analysis in Model 1 of Table 2 shows a significant positive coefficient for owner/manager knowledge (Knowledge), suggesting that the use of advisory services is positively related to the owner/manager knowledge, thereby confirming Hypothesis $1(\mathrm{p}<0.01)$. It also indicates that the use of advisory services also is significantly positively associated with the technical competence (Competence), which provides support for Hypothesis $2(\mathrm{p}<0.01)$. Additionally, the Hypothesis 3 receiving support which posits a positive relationship between competitive intensity (Competition) and use of advisory services $(\mathrm{p}<0.01)$. Support is also provided for Hypothesis $4(\mathrm{p}<0.01)$ which posits the more the complexity of the marketing decisions facing the firm, the more the use the external accountants' advisory services. In addition, we included control variables in Model 2. Consequently, the results suggest that all independent variables (owner/manager knowledge, technical competence, competitive intensity and complexity of market decisions) were remained significant $(\mathrm{p}<0.01$, respectively), but firm size and firm age are not associated with utilisation of advisory services.

Besides, a linear regression analysis was undertaken to test the association between the utilization of advisory services as the independent variable and performance as the dependent variable in Model 3. Support is also provided for Hypothesis $5(\mathrm{p}<0.01)$ which posits the utilisation of advisory services is positively associated with SME performance. In addition, we also controlled for the impact of firm age and size of the firm on the association between utilisation of advisory services and firm performance in Model 4, and found that the use of advisory services statistically positively associated with firm performance $(\mathrm{p}<0.01)$, and negatively associated with firm size $(\mathrm{p}<0.05)$, but it was unrelated to firm age.

\section{Discussion and conclusions}

In this paper, we have examined from an emerging economy's context, the factors that influence a firm's decision to obtain external accountants' advisory services and its impact on SME performance. Based on the resource-based perspective, this study examined how external resources that are considered valuable by SMEs and utilised by them in fulfilling the internal resource gaps and influence SME performance. Consequently, our empirical analysis indicated owner/manager knowledge is positively associated with the use of external accountants' advisory services. In other words, firms with owner/managers having high levels of knowledge in accounting will use external accountants' advisory services more than those firms that with owner/managers having low levels of knowledge. Therefore, our finding corroborates prior studies conducted by Audet and St-Jean(2007), indicated when the SME managers know more about the external service providers, they will utilise higher their services, and Ismail and King (2007), found the use of accounting information system was associated with SME owner/manager knowledge of accounting techniques. We also found a positive association between the utilisation of advisory services and technical competence. This finding is consistent with the results of the previous studies (Carey et al., 2006; Gooderham et al., 2004), suggesting that the technical competence is associated with the use of external accountants' services. More importantly, our results also revealed that an SME operating in a competitive environment turns to the external accountant for support services and advice. In other words, the use of advisory services of an external accountant is positively related to competitive intensity. This result is contradictory with a prior study conducted in Norway (Gooderham et al., 2004), which indicated that business advice of external accountant was not related to the degree of competition. We believe the reasons could be threefold: Firstly, the prior research was undertaken in a more developed country, whereas present study was conducted in lesser developing country such as Iran, hence emphasising the importance of the RBV theorization and its applicability in an emerging economy context; Secondly, the sample of this study included small and medium sized-enterprises whereas prior research (Gooderham et al., 2004) focused on micro and small enterprises (20 employees), hence suggesting an impact of size on the need for outsourcing of services; Finally, we examined five types of advisory services provided by external accountant, whereas prior study tested only business advice of an external accountant, clearly this indicates the importance of variety of services for an emerging economy. This study also examined the association between complexity of marketing decisions and the use of external accountants' advisory services, and found the usage of the external accountants' advisory services is positively related to the complexity of marketing decisions. This finding indicates that owner/managers are willing to use external accountants when the firm has many different products, market segments, and customers. Our finding is in line with prior research (Dyer and Ross, 2008) which demonstrated that the more complex the marketing decision, the more the small business manager is likely to seek business advice.

We also introduced the size and age of the firm as control variables in our regression equation. Accordingly, the 
relationship between the use of advisory services and four independent variables (owner/manager knowledge, technical competence, competitive intensity and complexity of market decisions) remained positively significant, but the use of advisory services was not associated with the size and age of the firm. This finding is similar to Gooderham et al. (2004) who found that the sourcing of business advice from external accountants was not associated with firm size and Everaert et al. (2010) who found that outsourcing of accountants' services is not associated with firm age.

More importantly, this study examined the relationship between the use of advisory services and SME performance, and found that a firm performance improves directly to the extent to which the firm engages an external accountant as advisor. Our finding is consistent with prior studies that indicated the usage of advisory services from an external accountant had a significant positive influence on firm performance (Berry et al., 2006), but this result conflicts with the research conducted in the UK by Robson and Bennett (2000) which indicated external accountants' business advice is not associated with SME performance. Therefore, we can speculate that this may due to the context of the developed economy where the SME entrepreneurs could be sufficiently literate on financial and management issues. For instance, in emerging economy, most SMEs face difficulty in attracting and retaining skilled employee (Kamyabi and Devi, 2011; Devi and Samujh, 2010). This is as a result of fewer experts and insufficient knowledgeable accounting support to carry out accounting tasks (Jayabalan et al. 2009; Kamyabi and Devi, 2011). Thus, SMEs in the emerging economy may experience greater need to utilise external accountants relative to more developed economy to get benefit from their services (Kamyabi and Devi, 2011; Devi and Samujh, 2010; Jayabalan et al., 2009). Furthermore, the link between the utilisation of advisory services and performance remained significant after including control variables in our regression equation.

\subsection{Research and practical implications}

This study revealed some research and practical implications. First, this study examined the effect of the utilisation of external accountants' services on SME performance and confirms previous research (Berry et al., 2006), and also extends by including knowledge of owner/manager, technical competence, complexity of marketing decisions and competitive intensity as critical factors affecting a firm's decision to utilise external accountants' services, this makes a contribution to the literature on emerging economies. Second, this study analysed the effect of external accountants' services and SME performance from the RBV, this provides some empirical findings not shown in previous studies. Third, this work is the first to analyse the external accountants' services in the Iranian context of an emerging economy and it also explicitly discusses the services currently provided by accountants to SME sector and examines the role that accountants play in Iranian context. Therefore, by identifying the broader range of services currently provided by external accountants to SMEs and the benefit attached to these services brings into focus the broader range of choices available to SME owner/managers. Fourth, SMEs constitute over ninety percent of enterprises in Iran as an emerging economy. However, majority of SMEs face limited capacity and expertise in-house, and they normally seek support services and advice because of their necessity. Clearly, professional accountants are in a unique position to fulfill the needs of SMEs, but it is important that the advisory and support services are provided by professional accountants to SMEs are fit for purposes (e.g. relevant and high quality).

\section{References}

Ale-Ebrahim, N., Ahmed, S., \& Taha, Z. (2010). Critical factors for new product developments in SMEs virtual team. African Journal of Business Management, 4(11), 2247-2257. [Online] Available: http://papers.ssrn.com/sol3/papers.cfm?abstract_id=1688931

ArabSalehi, M., \& Velashani, M. A. B. (2009). Financial Reporting Gap in Developing Countries: The Case Study of Iran. Middle Eastern Finance and Economics, (3), 77-78. [Online] Available: http://www.eurojournals.com/MEFE.htm

Armstrong, J., \& Overton, T. (1997). Estimating non-response bias in mail surveys. Journal of Marketing Research, 14(3), 396-402. [Online] Available: http://www.jstor.org/stable/i358111

Audet, J., \& St-Jean, E. (2007). Factors affecting the use of public support services by SME owners: evidence from a periphery region of Canada. Journal of Developmental Entrepreneurship, 12(2), 165-180. doi:10.1142/S1084946707000629, http://dx.doi.org/10.1142/S1084946707000629

Bayati, A., \& Taghavi, A. (2007). The impacts of acquiring ISO 9000 certification on the performance of SMEs in Tehran. The TQM Magazine, 19(2), 140-149. doi:10.1108/09544780710729980, http://dx.doi.org/10.1108/09544780710729980

Bennett, R. (2008). SME policy support in Britain since the 1990s: what have we learnt? Environment and 
Planning C: Government and Policy, 26, 375-397. [Online] Available: http://www.envplan.com/epc/fulltext/c26/c07118.pdf

Bennett, R., \& Robson, P. (1999). The use of external business advice by SMEs in Britain. Entrepreneurship and Regional Development, 11(2), 155-180. doi:10.1080/089856299283245, http://dx.doi.org/10.1080/089856299283245

Bennett, R., \& Robson, P. (2003). Changing use of external business advice and government support by SMEs in the 1990s. Regional Studies, 37(8), 795-811. doi:10.1080/0034340032000128721, http://dx.doi.org/10.1080/0034340032000128721

Berry, A. J., Sweeting, R., \& Goto, J. (2006). The effect of business advisers on the performance of SMEs. Journal of small Business and Enterprise Development, 13(1), 33-47. doi:10.1108/14626000610645298, http://dx.doi.org/10.1108/14626000610645298

Blackburn, R., \& Jarvis, R. (2010). The role of small and medium practices in providing business support to small- and medium-sized enterprises. Information Paper, International Federation of Accountants, April.

Blackburn, R., Carey, P., \& Tanewski, G. A. (2010). Business Advice to SMEs: Professional Competence, Trust and Ethics. Certified Accountants Educational Trust. The Association of Chartered Certified Accountants, 29 Lincoln's Inn Fields, London WC2A 3EE. ISBN: 978-1-85908-465-6.

Caldeira, M. M., \& Ward, J. M. (2003). Using resource-based theory to interpret the successful adoption and use of information systems and technology in manufacturing small and medium-sized enterprises. European Journal

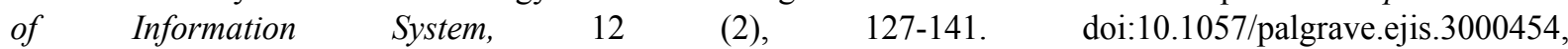
http://dx.doi.org/10.1057/palgrave.ejis.3000454

Carey, P., Simnett, R., \& Tanewski, G. (2005). Providing Business Advice for Small to Medium Enterprises. Melbourne: CPA Australia.

Carey, P., Subramaniam, N., \& Ching, K. C. W. (2006). Internal audit outsourcing in Australia. Accounting and Finance, $\quad 46, \quad 11-30 . \quad$ doi:10.1111/j.1467-629X.2006.00159.x, http://dx.doi.org/10.1111/j.1467-629X.2006.00159.x

Collis, J., \& Jarvis, R. (2002). Financial information and the management of small private companies. Journal of Small Business and Enterprise Development, 9(2), 100-110. doi:10.1108/14626000210427357, http://dx.doi.org/10.1108/14626000210427357

Devi, S. S., \& Samujh, R. H. (2010). Accountants as Providers of Support and Advice to SMEs in Malaysia (Research report No. 118). ACCA, London

Doran, M. (2006). Bean counter or business adviser? An exploratory study of changing times for the accounting practitioner in Ireland. The Irish Accounting Review, 13(1), 23-46. [Online] Available: http://www.highbeam.com/doc/1P3-1255755201.html

Doving, E., \& Gooderham, P. N. (2005). Small firm accountancy practices as business advisors: a dynamic capabilities view of the scope of their services. (No. 65/05). Norway, Institute for research in economics and business administration.

Doving, E., \& Gooderham, P. N. (2008). Dynamic capabilities as antecedents of the scope of related diversification: the case of small firm accountancy practices. Strategic Management Journal, 29(8), 841-857. doi:10.1002/smj.683, http://dx.doi.org/10.1002/smj.683

Dyer, L. M., \& Ross, C. A. (2008). Seeking advice in a dynamic and complex business environment: Impact on the success of small firms. Journal of Developmental Entrepreneurship, 13(2), 133-149. doi:10.1142/S1084946708000892, http://dx.doi.org/10.1142/S1084946708000892

Espino-Rodríguez, T. F., \& Padrón-Robaina, V. (2004). Outsourcing and its impact on operational objectives and performance: a study of hotels in the Canary Islands. Hospitality Management, 23(287-306). doi:10.1016/j.ijhm.2003.11.004, http://dx.doi.org/10.1016/j.ijhm.2003.11.004

Everaert, P., Sarens, G., \& Rommel, J. (2006). Outsourcing of Accounting Tasks in SMEs: An extended TCE Model (Working Paper No. 2004/403). Gent: Univeersiteit Gento.

Everaert, P., Sarens, G., \& Rommel, J. (2007). Sourcing strategy of Belgian SMEs: empirical evidence for the accounting services. Production Planning \& Control, 18(8), 716-725. doi:10.1080/09537280701706195, http://dx.doi.org/10.1080/09537280701706195 
Everaert, P., Sarens, G., \& Rommel, J. (2010). Using Transaction Cost Economics to explain outsourcing of accounting. Small Bus Econ, 35(1), 93-112. doi:10.1007/s11187-008-9149-3, http://dx.doi.org/10.1007/s11187-008-9149-3

Feizpour, M. A., \& Jamali, R. (2009). SMEs Employees Gender Composition and Firm Growth: Evidence from Manufacturing Industry in Cooperative Sector during the Second Development Plan in Iran from 1995 to 1999. International Review of Business Research Papers, 5(3), 311-332. [Online] Available: http://www.bizresearchpapers.com/24-Feizi.pdf

Ghanatabadi, F. (2005). Internationalization of Small and Medium-Sized Enterprises in Iran. Unpublished Doctoral thesis. Luleå University of Technology.

Gilley, K. M., Greer, C. R., \& Rasheed, A. A. (2004). Human resource outsourcing and organizational performance in manufacturing firms. Journal of Business Research, 57, 232-240. doi:10.1016/S0148-2963(02)00304-1, http://dx.doi.org/10.1016/S0148-2963(02)00304-1

Gooderham, P. N., Tobiassen, A., Doving, E., \& Nordhaug, O. (2004). Accountants as sources of business advice for small firms. International Small Business Journal, 22(1), 5-22. doi:10.1177/0266242604039478, http://dx.doi.org/10.1177/0266242604039478

Gottschalk, P., \& Solli-Sæther, H. (2005). Critical success factors from IT outsourcing theories: an empirical study. Industrial Management \& Data Systems, 105(6), 685-702. doi:10.1108/02635570510606941, http://dx.doi.org/10.1108/02635570510606941

Hafeez, K., Malak, N., \& Zhang, Y. B. (2007). Outsourcing non-core assets and competences of a firm using analytic hierarchy process. Computers \& Operations Research, 34, 3592 - 3608. doi:10.1016/j.cor.2006.01.004, http://dx.doi.org/10.1016/j.cor.2006.01.004

ILO. (2003). An Employment Strategy for the Islamic Republic of Iran: A Report Prepared for The Government of The Islamic Republic of Iran in Collaboration with the Ministry Labour and Social Affairs under UNDP SPPD funding.

[Online]

Available: http://www.ilo.org/asia/whatwedo/publications/lang--en/facet--TYP-_-Publication-_-GEO__-IRN\%2C-_-2627/in dex.htm

Irwin, J., Hoffman, J., \& Lamont, B. (1998). The effect of the acquisition of technological innovations on organizational performance: a resource-based view. Journal of Engineering \& Technology Management, 15(1), 23-54. doi:10.1016/S0923-4748(97)00028-3, http://dx.doi.org/10.1016/S0923-4748(97)00028-3

Ismail, N. A., \& King, M. (2005). Firm performance and AIS alignment in Malaysian SMEs. international Journal of Accounting Information Systems, 6, 241-259. doi:10.1016/j.accinf.2005.09.001, http://dx.doi.org/10.1016/j.accinf.2005.09.001

Ismail, N. A., \& King, M. (2007). Factors influencing the alignment of accounting information systems in small and medium sized Malaysian manufacturing firms. Journal of Information Systems and Small Business, 1 (1-2), $1-20$. doi:10.1.1.87.1722\&rep=rep1\&type=pdf, http://citeseerx.ist.psu.edu/viewdoc/download?doi=10.1.1.87.1722\&rep=rep1\&type=pdf.

Ismail, N. A., \& Zin, R. M. (2009). Usage of Accounting Information among Malaysian Bumiputra Small and Medium Non-Manufacturing Firms. Journal of Enterprise Resource Planning Studies, 1(2), 11-17. [Online] Available: http://eprints.uum.edu.my/id/eprint/1751

Jayabalan, J., Raman, M., Dorasamy, M., \& Ching, N. K. C. (2009). Outsourcing of Accounting Functions amongst SME Companies in Malaysia: An Exploratory Study. Accountancy Business and the Public Interest, 8(2), 96-114. [Online] Available: http://visar.csustan.edu/aaba/Dorasamy2009.pdf

Johnson, S., Webber, D. J., \& Thomas, W. (2007). Which SMEs use external business advice? A multivariate subregional study. Environment and Planning A, 39, 1981 - 1997. doi:10.1068/a38327, http://dx.doi.org/10.1068/a38327

Kamyabi, Y., \& Devi, S. (2011). An Empirical Investigation of Accounting Outsourcing in Iranian SMEs: Transaction Cost Economics and Resource-Based Views. International Journal of Business and Management, 6(3), 81-94. [Online] Available: http://ccsenet.org/journal/index.php/ijbm/article/viewFile/9694/6948.

Kirby, D. A., Najak.B., \& Greene.F. (1998). Accounting for growth: Ways accountants can add value to small businesses. The Research Board, ICAEW. London.

Leung, P., Raar, J., \& Tangey, G. (2008). Accounting Services and SMEs: An Australian Study. ACCA research 
report, No. 99. (London: CAET).

Lewis, K., Massey, C., Ashby, M., Coetzer, A., \& Harris, C. (2005). Who? When? Why? - New Zealand SME owner-managers assess their Business Assistance Interactions, Paper presented at the 8th Annual SEAANZ Conference 2005 UNE, Armidale, 25-28 September.

Liddicoat, D. L., \& Stringer, D. (2005). Perceptions of Support Services Available in Nelson For Small Medium Enterprises (SMEs) (Working Paper No. 4/2005). Nelson Marlborough Institute of Technology. New Zealand.

Lowe, P., \& Talbot, H. (2000). Providing advice and information in support of rural microbusinesses. University of Newcastle, Centre for Rural Economy.

Mahmoodzadeh, E., Jalalinia, S., \& Yazdi, F. N. (2009). A business process outsourcing framework based on business process management and knowledge management. Business Process Management Journal, 15(6), 845-864. doi:10.1108/14637150911003748, http://dx.doi.org/10.1108/14637150911003748

Marriott, N., \& Marriott, P. (2000). Professional accountants and the development of a management accounting service for the small firm: barriers and possibilities. Management Accounting Research, 11, 475-492. doi:10.1006/mare.2000.0142, http://dx.doi.org/10.1006/mare.2000.0142

Marriott, N., Marriott, P., Collis, J., \& Son, D. D. (2008). The Accountant and the Provision of Financial Advice to UK Smaller Companies. Paper presented at the British Accounting Association Annual Conference 1st-3rd April 2008. Blackpool.

Mashayekhi, B., \& Mashayekh, S. (2008). Development of accounting in Iran. The International Journal of Accounting, 43, 66-86. doi:10.1016/j.intacc.2008.01.004, http://dx.doi.org/10.1016/j.intacc.2008.01.004

McIvor, R. (2009). How the transaction cost and resource-based theories of the firm inform outsourcing evaluation. Journal of Operations Management, 27, 45-63. doi:10.1016/j.jom.2008.03.004, http://dx.doi.org/10.1016/j.jom.2008.03.004

Mirshekary, S., \& Saudagaran, S. M. (2005). Perceptions and characteristics of financial statement users in developing countries: Evidence from Iran. Journal of International Accounting, Auditing and Taxation, 14, 33-54. doi:10.1016/j.intaccaudtax.2005.01.001, http://dx.doi.org/10.1016/j.intaccaudtax.2005.01.001

Mole, K. (2002). Business Advisers' Impact on SMEs: An Agency Theory Approach. International Small Business Journal, 20(2), 139-162. [Online] Available: http://www.highbeam.com/doc/1G1-86867288.html

Naderian, H. (2010). Several obvious and significant differences in professional services in Iran. Journal of Iranian Certified Public Accountants, 8, 44-45 (in Persian).

Nejad, O. D. (2010). A note on the post-revolution iranian economy and the banking sector. Middle Eastern Finance and Economics, (6), 91-98. [Online] Available: http://www.eurojournals.com/mefe-6_09.pdf

OECD. (2009). The impact of the global crisis on SME and entrepreneurship financing and policy responses. Centre for Entreprenuership, SMEs and Local Development. Organisation for Economic Co-operation and Development.

Penrose, E. T. (1959). The Theory of the Growth of the Firm, Basil Blackwell, Oxford.

Pineda, R. C., Lerner, L. D., Miller, M. C., \& Phillips, S. J. (1998). An investigation of the factors affecting the information-search activities of small business managers. Journal of Small Business Management, 36(1), 60-71. [Online] Available: http://www.questia.com/googleScholar.qst?docId=5001327457

Rivard, S., Raymond, L., \& Verreaul, D. (2006). Resource-based view and competitive strategy: An integrated model of the contribution of information technology to firm performance. Journal of Strategic Information Systems, 15, 29-50. doi:10.1016/j.jsis.2005.06.003, http://dx.doi.org/10.1016/j.jsis.2005.06.003

Robson, P. J. A., \& Bennett, R. J. (2000). SME Growth: The Relationship with Business Advice and External Collaboration. Small Business Economics, 15(3), 193-208. doi:10.1023/A:1008129012953, http://dx.doi.org/10.1023/A:1008129012953

Salehi, M., \& Azary, Z. (2008). Fraud Detection and Audit Expectation Gap: Empirical Evidence from Iranian Bankers. International Journal of Business and Management, 3(10), 65-77. [Online] Available: http://ccsenet.org/journal/index.php/ijbm/article/view/1043

Sarapaivanich, N., \& Kotey, B. (2006). The effect of financial information quality on ability to access external funds and performance of SMEs in Thailand. Journal of Enterprising Culture, 14(3), 219-239. [Online] Available: http://ideas.repec.org/a/wsi/jecxxx/v14y2006i03p219-239.html 
Scott, J. M., \& Irwin, D. (2009). Discouraged advisees? The influence of gender, ethnicity, and education in the use of advice and finance by UK SMEs. Environment and Planning C: Government and Policy, 27, 230-245. doi:10.1068/c0806b, http://dx.doi.org/10.1068/c0806b

Sian, S., \& Roberts, C. (2009). UK small owner-managed businesses: accounting and financial reporting needs. Journal of small Business and Enterprise Development, 16(2), 289-305. doi:10.1108/14626000910956065, http://dx.doi.org/10.1108/14626000910956065

UNIDO. (2003). To enhance the contribution of an efficient and competitive small and medium-sized enterprise sector to industrial and economic development in the Islamic republic of Iran. [Online] Available: http://www.unido.org/fileadmin/import/18229_AbsFinal.pdf:

Watson. (2003). The potential impact of accessing advice on SME failure rates. Paper presented at the Small Enterprise Association of Australia and New Zealand 16th Annual Conference, Ballarat, 28 September.

Worrall, L. (2007). Transforming regional economic performance through business transformation. International Journal of Management Practice, 2(4), 324-344. doi:10.1504/IJMP.2007.012749, http://dx.doi.org/10.1504/IJMP.2007.012749

Zohari, T. (2008). Iranian government globalization policy impacts on SMEs and the corresponding effect on Iranian-Swedish trade. [Online] Available: http://digitpro.co.uk/paper/iran_sweden.pdf.

Table 1. Descriptive statistics and correlations

\begin{tabular}{|l|l|l|l|l|l|l|l|l|l|l|}
\hline Variables & Mean & S.D & 1 & 2 & 3 & 4 & 5 & 6 & 7 & 8 \\
\hline 1-Performance & 5.25 & 1.10 & 1 & & & & & & & \\
\hline 2-Advisory & 3.80 & 1.78 & $0.388^{* *}$ & 1 & & & & & & \\
\hline 3-knowledge & 4.62 & 1.48 & $0.392^{* *}$ & $0.443^{* *}$ & 1 & & & & & \\
\hline 4- Competence & 5.03 & 1.46 & $0.356^{* *}$ & $0.532^{* *}$ & $0.444^{* *}$ & 1 & & & & \\
\hline 5-Competition & 4.73 & 1.41 & $0.391^{* *}$ & $0.429^{* *}$ & $0.368^{* *}$ & $0.540^{* *}$ & 1 & & & \\
\hline 6-MktDecision & 4.73 & 1.61 & $0.305^{* *}$ & $0.475^{* *}$ & $0.297^{* *}$ & $0.469^{* *}$ & $0.360^{* *}$ & 1 & & \\
\hline 7-Firm Size & 2.79 & 1.42 & $-0.103^{*}$ & 0.010 & $0.127^{* *}$ & $0.100^{*}$ & -0.043 & 0.047 & 1 & \\
\hline 8-Firm Age & 3.82 & 1.57 & -0.018 & 0.053 & 0.102 & $0.086^{*}$ & -0.019 & $0.090^{*}$ & $0.503^{* *}$ & 1 \\
\hline
\end{tabular}

$* *$ correlation is significant at the 0.01 level (2-tailed)

*correlation is significant at the 0.05 level (2-tailed) 
Table 2. Results of regression analyses

\begin{tabular}{|l|l|l|l|l|}
\hline \multirow{2}{*}{ Variables } & \multicolumn{2}{|c|}{ Advisory Services } & \multicolumn{2}{c|}{ Performance } \\
\cline { 2 - 6 } & \multicolumn{1}{|c|}{ Model 1 } & Model 2 & Model 3 & Model 4 \\
\cline { 2 - 6 } & Coefficient(S.E) & Coefficient(S.E) & Coefficient(S.E) & Coefficient(S.E) \\
\hline Knowledge & $0.148(0.027)^{* *}$ & $0.147(0.027)^{* *}$ & - & - \\
\hline Competence & $0.241(0.048)^{* *}$ & $0.249(0.049)^{* *}$ & - & - \\
\hline MktDecision & $0.306(0.059)^{* *}$ & $0.300(0.059)^{* *}$ & - & - \\
\hline AdvisoryService & - & - & $0.671(0.069)^{* *}$ & $0.670(0.069)^{* *}$ \\
\hline Firm Size & - & $-0.185(0.274)$ & - & $-0.1 .169(0.510)^{*}$ \\
\hline Firm Age & - & $0.135(0.249)$ & - & $0.283(0.464)$ \\
\hline Constant & $-4.580(1.434)$ & $-4.708(1.604)$ & $60.849(1.452)$ & $63.103(2.104)$ \\
\hline $\mathrm{R}^{2}$ & 0.385 & 0.388 & 0.151 & 0.160 \\
\hline Adjusted $\mathrm{R}^{2}$ & 0.380 & 0.380 & 0.149 & 0.155 \\
\hline F-value & 71.809 & 47.784 & 94.213 & 33.219 \\
\hline DF-Model & 4 & 6 & 1 & 3 \\
\hline DF-Error & 458 & 452 & 531 & 523 \\
\hline
\end{tabular}

Note: $\mathrm{n}=658$. Unstandardized coefficients reported. Numbers in parentheses are Standard Errors (S.E).

** Significant at the 0.01 level and * significant at the 0.05 level 